\title{
In vitro ESTABLISHMENT OF Eucalyptus AND Corymbia SPECIES FROM EPICORMIC SHOOTS
}

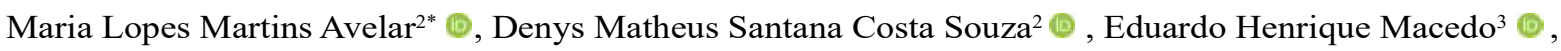 \\ Letícia Vaz Molinari $^{4}$ (-) and Gilvano Ebling Brondani ${ }^{5}$ ()
}

\footnotetext{
${ }^{1}$ Received on 29.03.2019 accepted for publication on 25.06.2020.

${ }^{2}$ Universidade Federal de Lavras, Programa de Pós-Gaduação em Engenharia Florestal, Lavras, MG-Brasil. E-mail: <maria.lma@hotmail. com> and <dmscsouza@gmail.com>.

${ }^{3}$ Klabin, Planejamento Florestal, Telêmaco Borba, PR-Brasil. E-mail: <eduardo.hmacedo@gmail.com>.

${ }^{4}$ Universidade Federal de Lavras, Programa de Pós-Gaduação em Agronomia , Lavras , MG-Brasil. E-mail: <leticia_vaz03@hotmail. com>.

${ }^{5}$ Universidade Federal de Lavras, Departamento de Ciências Florestais, Lavras , MG-Brasil. E-mail: <gilvano.brondani@ufla.br>.

*Corresponding author.
}

\begin{abstract}
The importance of Eucalyptus and Corymbia has been evident in forestry programs, mainly due to their adaptation to various environmental conditions and the multiple products that can be obtained. As the selection and cloning of superior individuals are usually performed in adulthood, the development and adaptation of the vegetative propagation techniques that enable the rescue and in vitro establishment of species are necessary. Thus, the present study aimed to induce epicormic shoots from pruned branches of adult trees and to promote the in vitro establishment of nine species: six of Eucalyptus and three of Corymbia. The material used to obtain the explants came from the selection of two 44-year-old mother plants of each species, from species, and provenance tests. The number of buds and shoots of each branch was evaluated at 15,25 , 35 , and 45 days after the beginning of the experiment in a greenhouse. According to the results, the induction of epicormic shoots from pruned branches was considered a viable and efficient technique to obtain propagule sources from adult mother plants of all species, presenting a gradual increase in the evaluated characteristics over time. Also, in vitro culture is an effective alternative to improve the propagation of the evaluated species, with an establishment of up to $62.5 \%$. However, for Corymbia citriodora (Hook.) K.D. Hill \& L.A.S Johnson and Eucalyptus tereticornis Smith it is necessary to develop further studies to enable the in vitro establishment.
\end{abstract}

Keywords: Shoot induction; In vitro culture; Vegetative propagation.

\section{ESTABELECIMENTO in vitro DE ESPÉCIES DE Eucalyptus E Corymbia POR MEIO DE BROTAÇÕES EPICÓRMICAS}

RESUMO-A importância de espécies dos gêneros Eucalyptus e Corymbia vem sendo evidenciada nos programas de silvicultura, principalmente pela adaptação em diversas condições ambientais e pelos múltiplos produtos que podem ser obtidos. Como a seleção e a clonagem de individuos superiores geralmente são realizadas na fase adulta, o desenvolvimento e a adequação de técnicas de propagação vegetativa que possibilitem o resgate e o estabelecimento in vitro de espécies desses gêneros são necessários. Dessa forma, o presente estudo teve como objetivo induzir brotos epicórmicos a partir de ramos podados de árvores adultas e promover o estabelecimento in vitro de nove espécies, sendo seis do gênero Eucalyptus e três de Corymbia. O material utilizado para a obtenção dos explantes foi proveniente da seleção de duas matrizes de cada espécie com 44 anos de idade, oriundas da implantação de um teste de espécies e procedências. Foram avaliados o número de gemas e brotos de cada ramo aos 15, 25, 35 e 45 dias após o início do experimento em casa de vegetação. De acordo com os resultados, a indução de brotações epicórmicas a partir de ramos podados foi considerada uma técnica viável e eficiente para obter fontes de propágulos de matrizes adultas de todas as espécies, apresentando um aumento gradual das características avaliadas ao longo do tempo. Além disso, o cultivo in vitro é uma alternativa eficaz para estabelecer propágulos a partir de brotações epicórmicas de árvores adultas da maioria das espécies avaliadas, com estabelecimento de até 62,5\%. Contudo, para Corymbia citriodora (Hook.) K.D.

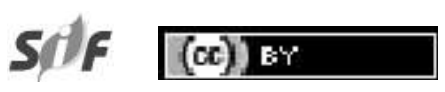

Revista Árvore 2020;44:e4427 http://dx.doi.org/10.1590/1806-908820200000027 
Hill \& L.A.S Johnson e Eucalyptus tereticornis Smith é necessário o desenvolvimento de mais estudos para viabilizar o estabelecimento in vitro.

Palavras-Chave: Indução de brotos; Cultivo in vitro; Propagação vegetativa.

\section{INTRODUCTION}

In the mid-1970s, eucalypts species and provenance tests were implemented in Brazil for testing potential species for industrial applications, aimed at possibly forming future forest plantations. The implementation of these tests was carried out through the 'Projeto de Desenvolvimento e Pesquisa Florestal (PRODEPEF)', together with the 'Instituto Brasileiro de Desenvolvimento Florestal (IBDF)' and 'Empresa Brasileira de Pesquisa Agropecuária (EMBRAPA)' (IPEF, 1984).

One of the last remaining and well-preserved test sites is in Lavras, Minas Gerais, in the Forest Nursery, Department of Forestry Sciences, Federal University of Lavras (UFLA), where seedlings produced from seeds from different regions of Australia were planted, comprising twenty-seven species in total, of the genera Eucalyptus and Corymbia.

The cloning of superior individuals, which aims to increase the homogeneity and productivity of stands or species conservation, involves steps that begin with the selection of genotypes, followed by the selection of vegetative propagation techniques. In most cases, this selection is only performed in the adult stage, where vegetative propagation has shown certain limitations, such as reduced rooting ability of cuttings due to the advanced maturity of plant tissues, which is linked to ontogenetic age (Wendling et al., 2014).

Several propagation techniques have been adopted to promote tissue rejuvenation and/or juvenile shoot induction in adult plants, such as girdling (Hartmann et al., 2011), cutting (Trueman et al., 2013), mini-cutting (Brondani et al., 2012a), coppicing (Xavier et al., 2013), epicormic shoot induction (Wendling et al., 2013) and micropropagation (Brondani et al., 2012b; Brondani et al., 2018; Souza et al., 2019a). These techniques can be used to rescue and clone selected trees (Baccarin et al., 2015).

Some of these techniques become infeasible due to the impossibility of slaughter or girdling of the mother plants in species and provenance tests. Thus, the induction of epicormic shoots from pruned branches of selected mother plants provides a feasible alternative for obtaining juvenile shoots (Wendling et al., 2013; Baccarin et al., 2015; Oliveira et al., 2015). These buds originate from latent axillary buds, called epicormic buds, are used to reconstitute the plant crown (Wendling et al., 2013) and can contribute to the propagation and multiplication of selected trees.

Thus, the objective of this study was to induce epicormic shoots from pruned branches of adult trees of species and provenance test and promote the in vitro establishment of nine species: six from the genus Eucalyptus and three from the genus Corymbia.

\section{MATERIALS AND METHODS}

\subsection{Study site and experimental material}

The experiments were conducted at the Forest Nursery and Laboratory of In Vitro Culture of Forest Species, belonging to the Department of Forestry Sciences of the Federal University of Lavras (UFLA), located in the municipality of Lavras, Minas Gerais (MG) state, Brazil (21 ${ }^{\circ} 14$ 'S latitude; $44^{\circ} 59^{\prime} \mathrm{W}$ longitude and $919 \mathrm{~m}$ altitude).

The material used to obtain the explants (nodal segments) originated from two 44-year-old mother plants of each species (Table 1), with six Eucalyptus species (Eucalyptus microcorys F. Muell., Eucalyptus grandis W. Hill ex Maiden, Eucalyptus camaldulensis Dehnh., Eucalyptus cloeziana F. Muell., Eucalyptus pilularis Smith and Eucalyptus tereticornis Smith), and three Corymbia species (Corymbia citriodora (Hook.) K.D. Hill \& L.A.S Johnson, Corymbia maculata (Hook.) K.D. Hill \& L.A.S Johnson and Corymbia torelliana (F. Muell.) K.D. Hill \& L.A.S. Johnson), derived from Eucalyptus and Corymbia species tested and with provenance in the Forest Nursery of UFLA in 1974 (IPEF, 1984).

\subsection{Collection and preparation of branches for the induction of epicormic shoots}

The mother plants were selected based on visual criteria, ensuring that the trunk was as straight as

Revista Árvore 2020;44:e4427 
Table 1 - Provenances and location of the selected mother plants in the species and provenance test of the nine species of Eucalyptus and Corymbia.

Tabela 1 - Procedências e localização das matrizes selecionadas no teste de espécies e procedências das nove espécies de Eucalyptus e Corymbia utilizadas.

\begin{tabular}{|c|c|c|c|c|c|c|c|}
\hline Species & Mother plants & Field & Identification & Provenances & Lat (S) & Long (E) & $\overline{\text { Alt (m) }}$ \\
\hline E. microcorys & M1 & B-8 & 8717 & Gympie & $26^{\circ} 11^{\prime}$ & $152^{\circ} 40^{\prime}$ & 100 \\
\hline E. microcorys & M2 & B-8 & 8717 & Gympie & $26^{\circ} 11^{\prime}$ & $152^{\circ} 40^{\prime}$ & 100 \\
\hline E. grandis & M1 & B-1A & 9753 & Coff's Harbour & $30^{\circ} 18^{\prime}$ & $153^{\circ} 08^{\prime}$ & 91 \\
\hline E. grandis & $\mathrm{M} 2$ & B-1A & 9753 & Coff's Harbour & $30^{\circ} 18^{\prime}$ & $153^{\circ} 08^{\prime}$ & 91 \\
\hline E. camaldulensis & M1 & B-1A & 10266 & Petford & $17^{\circ} 17^{\prime}$ & $145^{\circ} 59^{\prime}$ & $\overline{460}$ \\
\hline E. camaldulensis & M2 & B-1A & 10266 & Petford & $17^{\circ} 17^{\prime}$ & $145^{\circ} 59^{\prime}$ & $\overline{460}$ \\
\hline E. cloeziana & M1 & B-1C & 9785 & SW Kennedy & $18^{\circ} 17^{\prime}$ & $145^{\circ} 55^{\prime}$ & 122 \\
\hline E. cloeziana & M2 & B-1C & 9785 & SW Kennedy & $18^{\circ} 17^{\prime}$ & $145^{\circ} 55^{\prime}$ & 122 \\
\hline$\overline{\text { E. pilularis }}$ & M1 & B-1E & 9492 & Gallangowan & $26^{\circ} 30^{\prime}$ & $152^{\circ} 20^{\prime}$ & $\overline{580}$ \\
\hline E.pilularis & M2 & $\mathrm{B}-9(\mathrm{Y})$ & 6183 & $\begin{array}{c}\text { Mte. Glorius - } \\
\text { W Brisbane }\end{array}$ & $27^{\circ} 15^{\prime}$ & $152^{\circ} 40^{\prime}$ & $\overline{600}$ \\
\hline E. tereticornis & M1 & B-1C & 10054 & Atherton Dist. & $18^{\circ} 17^{\prime}$ & $145^{\circ} 58^{\prime}$ & 15 \\
\hline E. tereticornis & M2 & B-1C & 10054 & Atherton Dist. & $18^{\circ} 17^{\prime}$ & $145^{\circ} 58^{\prime}$ & 15 \\
\hline C. citriodora & M1 & B-1C & 10268 & W Herbeton & $17^{\circ} 24^{\prime}$ & $145^{\circ} 20^{\prime}$ & 853 \\
\hline C. citriodora & M2 & B-1C & 10268 & W Herbeton & $17^{\circ} 24^{\prime}$ & $145^{\circ} 20^{\prime}$ & 853 \\
\hline C. maculata & M1 & B-9(Y) & 6168 & W Brisbane & $27^{\circ} 15^{\prime}$ & $152^{\circ} 40^{\prime}$ & 550 \\
\hline C. maculata & M2 & B-9(Y) & 6168 & W Brisbane & $27^{\circ} 15^{\prime}$ & $152^{\circ} 40^{\prime}$ & 550 \\
\hline C. torelliana & M1 & B-1D & 10466 & Atherton Area & $17^{\circ} 12^{\prime}$ & $145^{\circ} 35^{\prime}$ & 694 \\
\hline C. torelliana & M2 & B-1D & 10466 & Atherton Area & $17^{\circ} 12^{\prime}$ & $145^{\circ} 35^{\prime}$ & 694 \\
\hline
\end{tabular}

Lat: latitude; Long: longitude; Alt: altitude. Source: Adapted from IPEF (1984).

Lat: latitude; Long: longitude; Alt: altitude. Fonte: Adaptado de IPEF (1984).

possible, free of pathogen attacks and had branches in the lower portion of the crown to minimize the effects of ontogenetic age (Almeida et al., 2007) and to facilitate the cutting and collection of the branches (Figure 1A).

The branches were sectioned into lengths of approximately $50 \mathrm{~cm}$ and placed in a greenhouse with controlled relative humidity and temperature $(\mathrm{RH}>$ $80 \%$; temperature between 20 and $35^{\circ} \mathrm{C}$ ) and irrigation by an intermittent misting system with high-pressure and low-flow nozzles, controlled automatically by a humidistat. These branches were placed vertically in polyethylene pots $(5 \mathrm{~L})$, which were filled with washed sand, without fertilization, for induction of epicormic shoots, for 45 days since collection, performed on the same day for all species (Figure 1B).

The experiment was arranged in a randomized block design, with six species of Eucalyptus and three species of Corymbia (i.e., nine species in total), with six replicates composed of plots with two branches per pot, totalling 108 branches. Total number of epicormic buds and the total number of shoots per branch at 15, 25, 35 and 45 days after installation of the experiment were evaluated.

\subsection{In vitro establishment}

Shoots (Figure $1 \mathrm{G}$ ) were collected after the branches stayed for 45 days in the greenhouse, being applied dimethyl 4,4'- (o-phenylene) bis (3-thioallophanate) fungicide $48 \mathrm{~h}$ before the shoot collection (i.e., concentration of $\left.0.5 \mathrm{~g} \mathrm{~L}^{-1}\right)$. Epicormic shoots with 4 to $5 \mathrm{~cm}$ of length were collected, immersed in autoclaved deionized water and transported to the laboratory.

The nodal segments (standardized with two axillary buds, without leaves, and 2 to $3 \mathrm{~cm}$ of length) were used as explants (Figure $1 \mathrm{H}$ ); these explants were washed in running water for $5 \mathrm{~min}$. Subsequently, they were immersed in $70 \%$ alcohol solution (v/v) for $30 \mathrm{~s}$ with constant agitation inside a horizontal laminar flow hood. They were then immersed in Clarix ${ }^{\circledR} \mathrm{NaOCl}$ solution (1.00-1.50\% of active chlorine) for $10 \mathrm{~min}$. The nodal segments were washed in autoclaved deionized water three times after immersion in alcohol and $\mathrm{NaOCl}$ and inoculated vertically under aseptic conditions in test tubes $(15.0 \mathrm{~cm} \times 2.5 \mathrm{~cm})$ containing $10 \mathrm{~mL}$ of MS culture medium (Murashige and Skoog, 1962). Throughout the entire process, the equipment used was disinfected with $70 \%$ alcohol solution $(\mathrm{v} / \mathrm{v})$.

\section{Revista Árvore 2020;44:e4427}



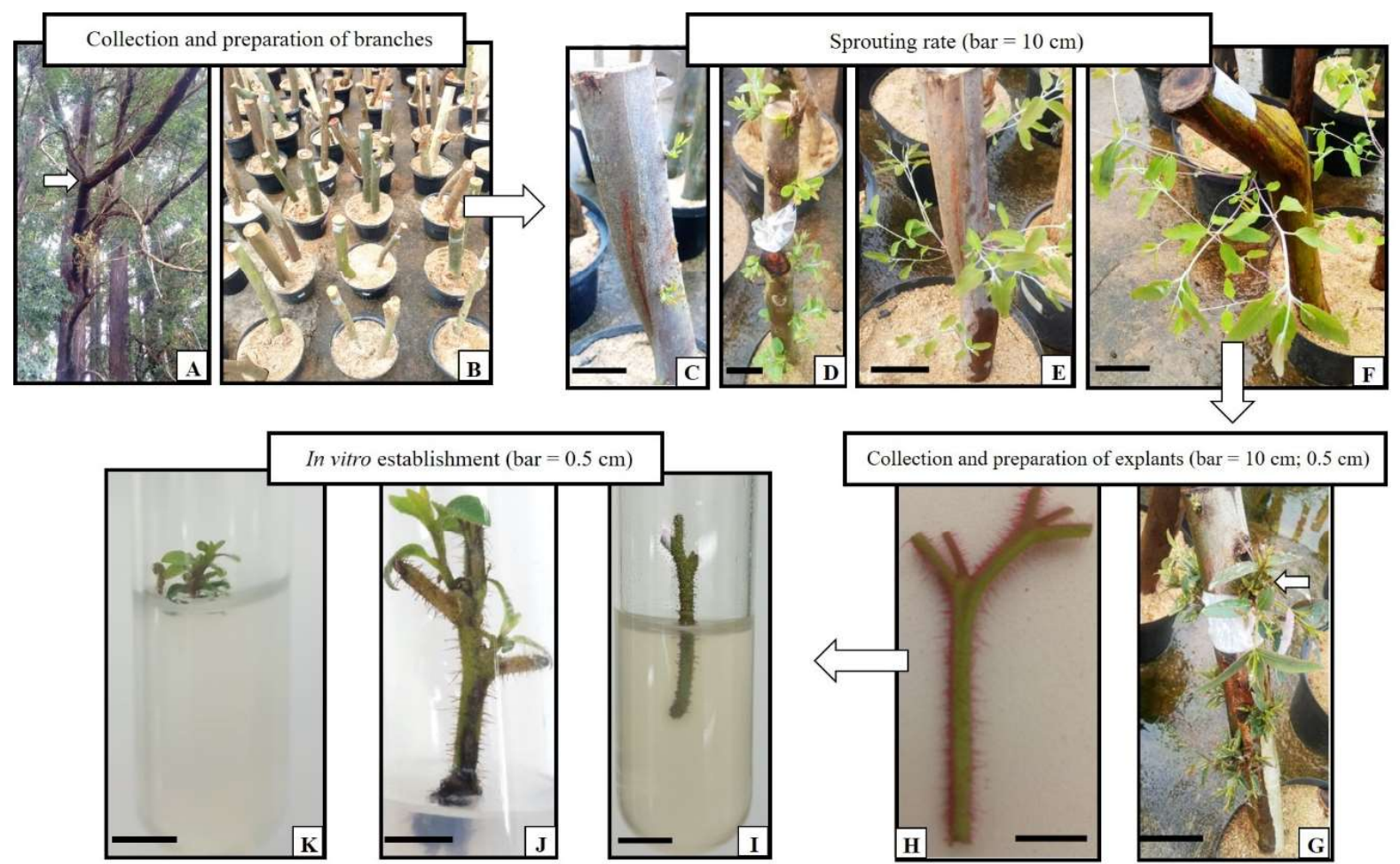

Figure 1 - Steps to obtain propagules from the selection and pruning of selected adult tree branches to the in vitro establishment of nodal segments prepared from epicormic shoots. (A) Selected mother plant, highlighting the portion used to obtain the branches; (B) Branches after standardization and arranged in a greenhouse; (C) Detail of Eucalyptus grandis shoots at 15 days; (D) Detail of Eucalyptus grandis shoots at 25 days; (E) Detail of Eucalyptus grandis shoots at 35 days; (F) Detail of Eucalyptus grandis shoots at 45 days; $(\mathrm{G})$ Epicormic shoots recently collected from the branches, highlighting the obtaining of the explants; $(\mathrm{H})$ Nodal segment after preparation; (I) Explant introduced in MS culture medium; (J) Beginning of in vitro establishment with the appearance of the first shoots; (K) In vitro established explant.

Figura 1 - Etapas para obtenção de propágulos desde a seleção e poda de ramos de árvores adultas selecionadas até o estabelecimento in vitro de segmentos nodais preparados a partir de brotações epicórmicas: (A) Matriz selecionada, destacando a porção utilizada para obtenção dos ramos; (B) Ramos após a padronização e dispostos em casa de vegetação; (C) Detalhe da brotação de $\boldsymbol{E}$. grandis aos 15 dias; (D) Detalhe da brotação de $\boldsymbol{E}$. grandis aos 25 dias; (E) Detalhe da brotação de $\boldsymbol{E}$. grandis aos 35 dias; $(F)$ Detalhe da brotação de E. grandis aos 45 dias; (G) Brotação epicórmica recém coletada dos ramos, destacando a obtenção dos explantes; (H) Segmento nodal após preparo; (I) Explante introduzido em meio de cultura MS; (J) Início do estabelecimento in vitro com o aparecimento das primeiras brotações; $(K)$ Explante estabelecido in vitro.

The time from explant collection in the field until inoculation in culture medium was less than $2 \mathrm{~h}$. During the collection, transport and intervals between disinfection and inoculation, the explants were kept immersed in autoclaved deionized water to prevent dehydration.

The culture medium was supplemented with $30 \mathrm{~g}$ $\mathrm{L}^{-1}$ of sucrose (Synth Ltda) and $6 \mathrm{~g} \mathrm{~L}^{-1}$ of agar (Merck S.A.), without adding of plant growth regulators. The culture medium was prepared using deionized water, and the $\mathrm{pH}$ was adjusted to $5.80 \pm 0.05$ with $\mathrm{NaOH}(0.1 \mathrm{M})$ and $\mathrm{HCl}(0.1 \mathrm{M})$ before autoclaving and the addition of the agar. The culture medium was autoclaved at $127^{\circ} \mathrm{C}$ and $1.5 \mathrm{kgf} \mathrm{cm}^{-2}$ of pressure for $20 \mathrm{~min}$.
After inoculation, the explants were kept in a growth room at $24 \pm 1^{\circ} \mathrm{C}$, a photoperiod of $16 \mathrm{~h}$ and irradiance of $40 \mu \mathrm{mol} \mathrm{m} \mathrm{m}^{-2} \mathrm{~s}^{-1}$ (quantified by radiometer, LI-COR ${ }^{\circledR}$, LI-250A Light Metre) for 35 days.

Regarding the in vitro establishment (Figure $1 \mathrm{~K})$, the experiment was performed in a completely randomized design, with nine species constituting the treatments with forty replicates composed of plots with one explant per test tube. At 35 days after inoculation for in vitro establishment, the following characteristics were evaluated: mean percentage of fungal and/or bacterial manifestation (i.e., in vitro contamination), oxidation of tissues, non-responsive explants (i.e., explants that showed green coloration and absence of oxidation,

Revista Árvore 2020;44:e4427 
however absence of bud and/or shoot emission), in vitro establishment (i.e., explants with absence of contamination, oxidation and which bud and/or shoot emission), length of shoots $(>0.5 \mathrm{~cm})$ and mean number of shoots per explant $(>0.5 \mathrm{~cm})$.

\subsection{Data analysis}

The analyses were performed using $\mathrm{R}$ Core Team software (2018), using the ExpDes package, version 1.1.2 (Ferreira et al., 2013). The data collected from the treatments were used to perform the polynomial regression analysis of the variables evaluated according to the evaluation times for each species in a greenhouse, and to perform statistical analysis (ANOVA) and Tukey's test at 5\% of probability for in vitro establishment of explants.

\section{RESULTS}

\subsection{Induction of epicormic buds and shoots}

The data observed between species of Eucalyptus and Corymbia for the number of buds and shoots in relation to the time of evaluation were better adjusted in polynomial curves of the second degree, in which they presented higher coefficient of determination $\left(\mathrm{R}^{2}\right)$ (Figure 2).

The number of buds (Figure 2), i.e. protruding meristems observed in the branches, from which the shoots were emitted, E. camaldulensis had the highest values ( 39 and 70 buds at 15 and 25 days in a greenhouse, respectively). However, in the first evaluation, at 15 days, E. cloeziana, C. citriodora, C. maculata, C. torelliana and $E$. tereticornis did not show epicormic buds. Subsequent evaluations resulted in a higher number of buds for E. grandis ( 80 and 87 buds at 35 and 45 days, respectively) and lower values for E. tereticornis ( 7 and 10 buds at 35 and 45 days, respectively) (Figure 2).

Among the species evaluated, regarding the sprouting rate (Figure 3), it was observed that, on the first evaluation (15 days), E. grandis had the highest number of shoots (54 shoots), while E. cloeziana, $C$. citriodora, C. maculata, C. torelliana and E. tereticornis did not show epicormic shoots. The largest number of shoots (159, 188 and 219 shoots at 25, 35 and 45 days, respectively) was observed for E. pilularis, with the lowest values observed for E. tereticornis in all evaluations, resulting in 14 shoots at 45 days. Throughout the experiment, a gradual increase was observed for the number of epicormic buds and shoots in relation to the different evaluation times $(15,25,35$ and 45 days after the beginning of the experiment).

\subsection{In vitro establishment}

At 35 days after inoculation in culture medium, the species exhibited significant differences for percentages of contamination, with the lowest mean $(20.0 \%)$ being observed for E. grandis (Figure 4A), which differed statistically from the species. On the other hand, $E$. tereticornis and C. citriodora reached, on average, $75.0 \%$ of contamination (Figure 4A), being one of the factors that limited the in vitro establishment, however they did not differentiate from E. cloeziana, E. microcorys and C. maculata.

Regarding phenolic oxidation in the tissues, the lowest means, 5 and $8 \%$, were observed, respectively, for E. pilularis and E. microcorys (Figure 4B), which differed significantly from the other species.

The amount of non-responsive explants in vitro (explants that showed green coloration and no oxidation, however absence of bud and shoot emission - Figure 1C) was statistically similar for E. camaldulensis, $C$. citriodora and E. tereticornis, in which all the explants were responsive, and for E. pilularis and E. grandis, in which both presented $5.0 \%$ of non-responsive explants.

Regarding the in vitro establishment (Figure 1D), E. pilularis $(60.0 \%)$ and E. grandis $(62.5 \%)$ showed the highest values. In contrast, no explants were established for C. citriodora and E. tereticornis.

The numbers of shoots induced from the explants (Figure 4E) in E. grandis (mean of 2.2 shoots), E. cloeziana (mean of 2.4 shoots), E. microcorys (mean of 1.9 shoots) and $C$. torelliana (mean of 2.5 shoots) were the highest observed, showing a significant difference from the other species. For the length of the shoots (Figure 4F), C. torelliana had the highest values (mean of $0.95 \mathrm{~cm}$ ), differing statistically only for species that could not be in vitro established.

\section{DISCUSSION}

\subsection{Induction of epicormic buds and shoots}

The induction of epicormic buds and shoots from pruned branches was considered a viable technique for all species studied, showing a gradual increase in the characteristics evaluated over time. Several

Revista Árvore 2020;44:e4427 


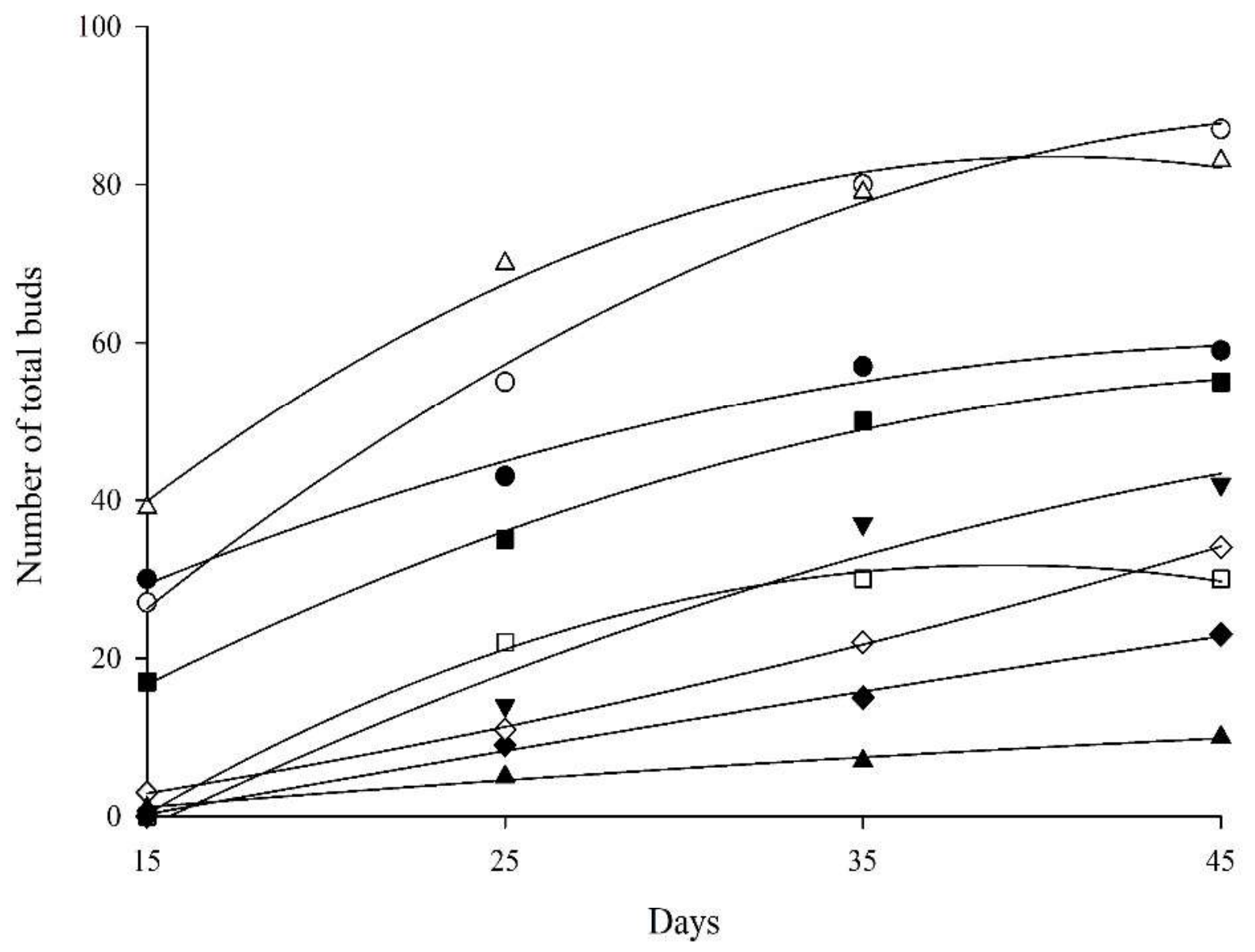

- $\mathrm{Y}$ E. pilularis $=-4.3625+2.660 \mathrm{x}-0.0275 \mathrm{x}^{2} \mathrm{R}^{2}=0.99$

- $\mathrm{Y}$ E. grandis $=-39.9375+5.20 \mathrm{x}-0.0525 \mathrm{x}^{2} \mathrm{R}^{2}=0.99$

$\nabla Y$ E. cloeziana $=-38.8875+2.840 \mathrm{x}-0.0225 \mathrm{x}^{2} \mathrm{R}^{2}=0.98$

$\triangle \quad \mathrm{Y}$ E. camaldulensis $=-26.8625+5.460 \mathrm{x}-0.0675 \mathrm{x}^{2} \mathrm{R}^{2}=0.99$

- $\mathrm{Y}$ E. microcorys $=-24.6375+3.240 \mathrm{x}-0.0325 \mathrm{x}^{2} \mathrm{R}^{2}=0.99$

$\square \quad \mathrm{Y}$ C. citriodora $=-51.525+4.280 \mathrm{x}-0.055 \mathrm{x}^{2} \mathrm{R}^{2}=0.99$

- Y C. maculata $=-12.6875+0.90 \mathrm{x}-0.0025 \mathrm{x}^{2} \mathrm{R}^{2}=0.99$

$\diamond \quad \mathrm{Y}$ C. toreliana $=-5.950+0.440 \mathrm{x}+0.010 \mathrm{x}^{2} \mathrm{R}^{2}=0.99$

A $\mathrm{Y}$ E. tereticornis $=-4.8875+0.440 \mathrm{x}-0.0025 \mathrm{x}^{2} \mathrm{R}^{2}=0.99$

Figure 2 - Number of buds observed in the pruned branches according to the evaluations $(15,25,35$ and 45 days after the beginning of the experiment in a greenhouse) of the nine species of eucalypts (Eucalyptus and Corymbia).

Figura 2 - Número de gemas observadas nos ramos podados em função das avaliações $(15,25,35$ e 45 dias após o início do experimento em casa de vegetação) das nove espécies dos gêneros Eucalyptus e Corymbia. 


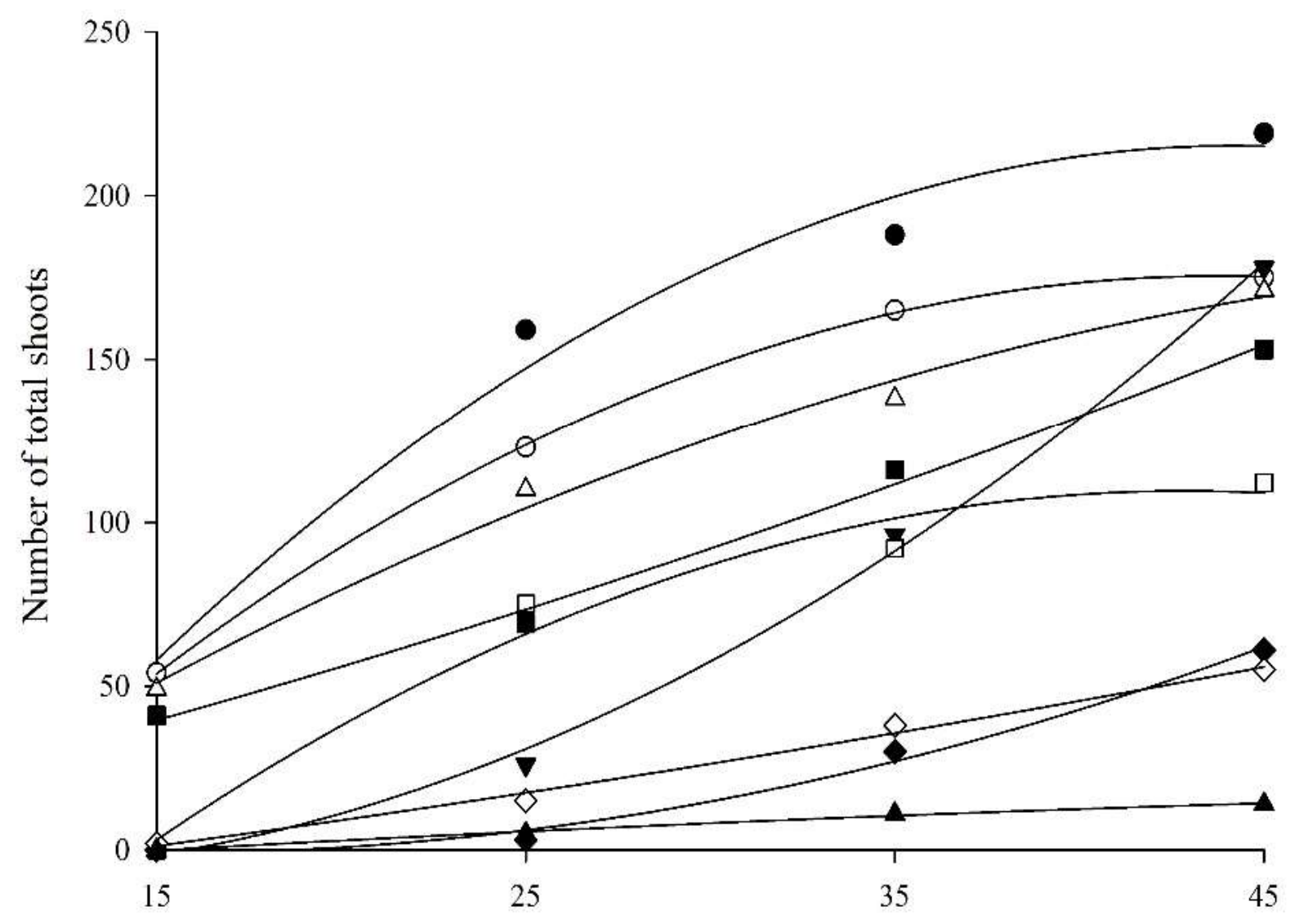

Days

- $\mathrm{Y}$ E. pilularis $=-145.575+16.340 \mathrm{x}-0.185 \mathrm{x}^{2} \mathrm{R}^{2}=0.99$

O $\mathrm{Y}$ E. grandis $=-106.5625+12.90 \mathrm{x}-0.1475 \mathrm{x}^{2} \mathrm{R}^{2}=0.99$

$\nabla Y$ E. cloeziana $=2.30-2.360 \mathrm{x}+0.140 \mathrm{x}^{2} \mathrm{R}^{2}=0.99$

$\triangle \quad \mathrm{Y}$ E. camaldulensis $=-55.45+8.140 \mathrm{x}-0.070 \mathrm{x}^{2} \mathrm{R}^{2}=0.99$

- $\mathrm{Y}$ E. microcorys $=-2.7125+2.480 \mathrm{x}+0.0225 \mathrm{x}^{2} \mathrm{R}^{2}=0.99$

ㄱ $\mathrm{Y}$ C. citriodora $=-142.7125+11.78 \mathrm{x}-0.1375 \mathrm{x}^{2} \mathrm{R}^{2}=0.98$

- $\mathrm{Y}$ C. maculata $=14.75-2.10 \mathrm{x}+0.070 \mathrm{x}^{2} \mathrm{R}^{2}=0.99$

$\diamond \quad \mathrm{Y}$ C. toreliana $=-19.35+1.220 \mathrm{x}+0.01 \mathrm{x}^{2} \mathrm{R}^{2}=0.99$

$\Delta \quad \mathrm{Y}$ E. tereticornis $=-10.775+0.78 \mathrm{x}-0.005 \mathrm{x}^{2} \mathrm{R}^{2}=0.99$

Figure 3 - Number of shoots observed in the pruned branches according to the evaluations $(15,25,35$ and 45 days after the beginning of the experiment in a greenhouse) of the nine species of eucalypts (Eucalyptus and Corymbia).

Figura 3 - Número de brotos observados a partir de gemas epicórmicas em função das avaliações $(15,25,35$ e 45 dias após o início do experimento em casa de vegetação) das nove espécies dos gêneros Eucalyptus e Corymbia. 



Figure 4 - Variables evaluated in the in vitro establishment of the nine species of eucalypts (Eucalyptus and Corymbia). (A) Percentage of contamination; (B) Percentage of oxidation; (C) Percentage of non-responsive explants; (D) Percentage of in vitro establishment; (E) Number of shoots per explant; (F) Shoot length. Mean with the same letter do not differ statistically from each other by the Tukey's test at $5 \%$ of probability.

Figura 4 - Variáveis avaliadas no estabelecimento in vitro das nove espécies dos gêneros Eucalyptus e Corymbia: (A) Porcentagem de contaminação; (B) Porcentagem de oxidação; (C) Porcentagem de explantes não responsivos; (D) Porcentagem de estabelecimento in vitro; (E) Número de brotos por explante; $(F)$ Comprimento de brotos. Médias com mesmas letras acima das colunas não diferem estatisticamente entre si pelo teste de Tukey à $5 \%$ de probabilidade de erro.

Revista Árvore 2020;44:e4427 
similar studies have indicated the efficiency of this rescue method, including plants of Ilex paraguariensis with 19-year-old (Wendling et al., 2013), Eucalyptus benthamii with 13-year-old (Baccarin et al., 2015) and Eucalyptus cloeziana with 26-year-old (Oliveira et al., 2015).

Wendling et al. (2013) used branches from adult individuals of Ilex paraguariensis to induce epicormic shoots and observed the emission of six shoots per pruned branch at 50 days. Nascimento et al. (2019) and Duarte et al. (2019), also working with Ilex paraguariensis, observed that the emission of epicormic shoots was efficient in the propagation of the species. In addition, Maggioni et al. (2020) reported the use of epicormic shoots as a way to promote higher rooting rates in Araucaria angustifolia.

According to Wendling et al. (2013) and Pires et al. (2013), the use of this technique is especially important for germplasm conservation and selection of superior individuals, for which rescue is normally performed in the adult stage when propagation may be limited due to ontogenetic age. The physiological principle for the induction of epicormic buds and shoots in pruned branches is related to the alteration of the balance in plant growth regulation (e.g., auxin and cytokinin), favoring the bud and shoot induction (Wendling et al., 2013).

The vegetative propagation of adult trees can be facilitated by the epicormic shoots induction, where tissues with a higher degree of juvenility can be obtained (Hartmann et al., 2011; Oliveira et al., 2015). However, in adulthood, vegetative propagation has shown limitations, such as reduced of adventitious rooting due to the advanced maturity of plant tissues (Wendling et al., 2014).

\subsection{In vitro establishment}

Epicormic shoots, obtained from pruned branches, have also been used as a source of explants for the micropropagation of Eucalyptus grandis (Ikemori, 1987), Quercus robur (Vieitez et al., 1994), Eucalyptus maidenii (Sotelo and Monza, 2007), Arbutus unedo (Gomes and Canhoto, 2009), Eucalyptus benthamii (Baccarin et al., 2015), Ilex paraguariensis (Wendling et al., 2013) and Eucalyptus cloeziana (Oliveira et al., 2015).

At 35 days after in vitro inoculation of Eucalyptus and Corymbia tissues, variations were observed through epicormic shoots. According to Trueman et al. (2018) the success of micropropagation is dependent on only a few explants forming shoots free of contamination, because the onset of in vitro propagation is a limiting phase.

However, when a large amount of micropropagated plants is required, higher rates of explants with shoots can be necessary to rapidly increase the number of clones produced. The different percentages of in vitro contamination demonstrate that the metabolic pathway of microorganisms may be regulated by the genotype, through differential genetic expression in carotenoid biosynthesis and hyphal aggregation (Postemsky and Curvetto, 2016).

As for phenolic oxidation, the percentages were considered low, despite the fact that these are mother plants with advanced ontogenetic age, from which higher oxidation values were expected. Phenolic oxidation has been a problem associated with the micropropagation of woody species, as reported in several studies with $E$. cloeziana (Oliveira et al., 2015), E. benthamii ( Brondani et al., 2012b; Baccarin et al., 2015), Eucalyptus dunnii ( Navroski et al., 2014), Corymbia citriodora $\times$ Corymbia torelliana and Corymbia torelliana $\times$ Corymbia citriodora (Souza et al., 2019b), which reported similar response.

This allows advancement to the multiplication phase, showing the importance of high induction rates. In E. cloeziana, Oliveira et al. (2015) obtained, on average, $51.2 \%$ explants with shoots. For Eucalyptus urophylla $\times$ E. globulus, Borges et al. (2012) observed 95.0\% of explants with shoots. Thus, different results are observed according to the genotype and the culture conditions.

The use of epicormic shoots as a source of explants for micropropagation allows the rejuvenation/ reinvigoration of tissues from mother plants in the field, which are usually found in the adult stage, when the tree tissues already show a certain level of maturity ( Trueman et al., 2018) In this context, epicormic shoots is an effective alternative for vegetative propagation of adult trees through in vitro culture.

\section{CONCLUSION}

The epicormic shoots from branches pruned is an efficient technique for the rescue of eucalypts mature trees with 44-year-old.

\section{Revista Árvore 2020;44:e4427}


In vitro culture is an alternative technique to improve the vegetative propagation of eucalypts adult trees, with establishment of $62.5 \%$, except for $C$. citriodora and $E$. tereticornis, which need further studies to enable in vitro establishment.

\section{ACKNOWLEDGMENTS}

We thank the National Council for Scientific and Technological Development, Brazil (Conselho Nacional de Desenvolvimento Científico e Tecnológico - CNPq), Coordination for Improvement of Higher Education Personnel, Brazil (Coordenação de Aperfeiçoamento de Pessoal de Nível Superior - CAPES - Código de Financiamento 001), and Foundation for Research of the State of Minas Gerais, Brazil (Fundação de Amparo a Pesquisa do Estado de Minas Gerais - FAPEMIG).

\section{REFERENCES}

Almeida FD, Xavier A, Dias JM. Propagação vegetativa de árvores selecionadas de Eucalyptus cloeziana F. Muell por estaquia. Revista Árvore. 2007;31(3):445-53. doi: doi.org/10.1590/S010067622007000300010

Baccarin FJB, Brondani GE, Almeida LV, Vieira IG, Oliveira LS, Almeida M. Vegetative rescue and cloning of Eucalyptus benthamii selected adult trees. New Forests. 2015;46(4):465-83. doi: doi. org/10.1007/s11056-015-9472-x

Borges SR, Xavier A, Oliveira LS, Lopes AP, Otoni WC, Takahashi EK, et al. Estabelecimento in vitro de clones híbridos de Eucalyptus globulus. Ciência Florestal. 2012;22(3):605-16. doi: doi. org/10.5902/198050986626

Brondani GE, Baccarin FJB, Wit Ondas HW, Stape JL, Gonçalves AN, Almeida M. Low temperature, IBA concentrations and optimal time for adventitious rooting of Eucalyptus benthamii minicuttings. Journal of Forestry Research. 2012a;23(4):583-92. doi: doi.org/10.1007/s11676-012-0298-5

Brondani GE, Oliveira LS, Konzen ER, Silva ALLD, Costa JL. Mini-incubators improve the adventitious rooting performance of Corymbia and Eucalyptus microcuttings according to the environment in which they are conditioned. Anais da Academia Brasileira de Ciências. 2018;90(2 supl.1):2409-23. doi: doi. org/10.1590/0001-3765201720170284
Brondani GE, Wit Ondas HW, Baccarin FJB, Gonçalves AN, Almeida M. Micropropagation of Eucalyptus benthamii to form a clonal micro-garden. In Vitro Cellular \& Developmental Biology - Plant. 2012b;48(5):478-87. doi: doi.org/10.1007/s11627012-9449-9

Duarte MM, Mireski MC, Oliszeski A, Wendling I, Stuepp CA. Rooting of yerba mate cuttings with different lengths. Revista Eletrônica Científica da UERGS. 2019;5(1):5-11. doi: doi. org/10.21674/2448-0479.51.6-12

Ferreira EB, Cavalcanti PP, Nogueira DA. ExpDes: experimental designs package. $\mathrm{R}$ package version 1.1.2. 2013

Gomes F, Canhoto JM. Micropropagation of strawberry tree (Arbutus unedo L.) from adult plants. In Vitro Cellular \& Developmental Biology - Plant. 2009;45(1):72-82. doi: doi.org/10.1007/s11627-0089164-8

Hartmann HT, Kester DE, Davies Junior FT, Geneve RL. Plant propagation: principles and practices. 8th ed. São Paulo: Prentice-Hall; 2011. ISBN 9780135014493.

Ikemori YK. Epicormic shoots from the branches of Eucalyptus grandis as an explant source for in vitro culture. Commonwealth Forestry Review. 1987;66(4):351-56.

Instituto de Pesquisas e Estudos Florestais - IPEF. Procedências de Eucalyptus spp introduzidas no Brasil por diferentes entidades. Boletim Informativo. 1984;10(29):259. Disponível em: <http://www.ipef. br/publicacoes/boletim_informativo/bolinf29.pdf $>$. Acesso em: 03 de dezembro de 2018.

Maggioni RA, Tomasi JC, Zuffellato-Ribas KC, Wendling I. Araucaria angustifolia: ácido indolbutírico e diferentes clones no enraizamento de estacas. Advances in Forestry Science. 2020;7(1):861-66. doi: doi.org/10.34062/afs. v7i1.7429

Murashige T, Skoog F. A revised medium for rapid growth and bioassays with tobacco tissue cultures. Physiologia Plantarum. 1962;15(3):473-97. doi: doi. org/10.1111/j.1399-3054.1962.tb08052.x

Nascimento B, Sá ACS, Souza G, Pereira

Revista Árvore 2020;44:e4427 
MO, Navroski MC. Nitrogenated fertilization favors vegetative rescue and propagation of Ilex paraguariensis. Cerne. 2019;25(1):76-83. doi: doi. org/10.1111/j.1399-3054.1962.tb08052.x

Navroski MC, Reiniger LRS, Araújo MM, Curti AR, Pereira MO. In vitro establishment and multiplication of genotypes of Eucalyptus dunnii Maiden. Cerne. 2014;20(1):139-46. doi: doi.org/10.1590/S010477602014000100017

Oliveira LS, Brondani GE, Batagin-Piotto $\mathrm{KD}$, Calsavara R, Gonçalves AN, Almeida M. Micropropagation of Eucalyptus cloeziana mature trees. Australian Forestry. 2015;78(4):219-31. doi: doi.org/10.1080/00049158.2015.1073211

Pires PP, Wendling I, Brondani G. Indol-butyric acid and orthotropism in minicutting of Araucaria angustifolia. Revista Árvore. 2013;37(3):393-99. doi: doi.org/10.1590/S0100-67622013000300002

Postemsky PD, Curvetto NR. In vitro studies of secondary metabolite-related responses in some species of genus Grifola (Agaricomycetes) from Argentina. International Journal of Medicinal Mushrooms. 2016;18(4):355-63. doi: doi. org/10.1615/IntJMedMushrooms.v18.i4.90

R Development Core Team. R: a language and environment for statistical computing. Vienna, Austria: R Foundation for Statistical Computing; 2018. Available at: <URL https://www.R-project. org/>

Sotelo M, Monza J. Micropropagation of Eucalyptus maidenii elite trees. Agrociencia. 2007;11(1):81-89.

Souza DMSC, Fernandes SB, Avelar MLM, Frade SRP, Molinari LV, Gonçalves DS, et al. Mixotrophism effect on in vitro elongation and adventitious rooting of Eucalyptus dunnii. Cerne. 2019a;25(4):394-01.

Souza DMSC, Xavier A, Otoni WC, Miranda NA, Maggioni JH. Light quality in the in vitro introduction of Corymbia hybrid clones. Revista Árvore. 2019b;42(6):1-9. doi: doi.org/10.1590/180690882018000600004

Trueman SJ, Hung CD, Wendling I. Tissue culture of Corymbia and Eucalyptus. Forests. 2018;9(2):1-42. doi: doi.org/10.3390/f9020084

Trueman SJ, McMahon TV, Bristow M. Production of cuttings in response to stock plant temperature in the subtropical eucalypts, Corymbia citriodora and Eucalyptus dunnii. New Forests. 2013;44(2):265-79. doi: doi.org/10.1007/s11056-012-9315-y

Vieitez AM, Sánchez MC, Amo-Marco JB, Ballester A. Foreed flushing of branch segments as a method for obtaining reactive explants of mature Quercus robur trees for micropropagation. Plant Cell, Tissue and Organ Culture. 1994;37(3):287-95. doi: doi. org/10.1007/BF00042342

Xavier A, Wendling I, Silva RL. Silvicultura clonal: princípios e técnicas. Viçosa: Editora UFV; 2013. ISBN 9788572694698.

Wendling I, Brondani GE, Biassio A, Dutra LF. Vegetative propagation of adult Ilex paraguariensis trees through epicormic shoots. Acta Scientiarum. Agronomy. 2013;35(1):117-25. doi: doi.org/10.4025/ actasciagron.v35i1.15958

Wendling I, Trueman SJ, Xavier A. Maturation and related aspects in clonal forestry - part II: reinvigoration, rejuvenation and juvenility maintenance. New Forests. 2014;45(4):473-86. doi: doi.org/10.1007/s11056-014-9415-y 


\section{ERRATA}

No ARTIGO "IN VITRO ESTABLISHMENT OF EUCALYPTUS AND CORYMBIA SPECIES FROM

EPICORMIC SHOOTS.”, PUBLICAdo No VOLUMe 44, da RevisTa ÁrVore, ONDE SE LÊ:

In vitro ESTABLISHMENT OF eucalyptus AND corymbia SPECIES FROM EPICORMIC SHOOTS

ESTABELECIMENTO in vitro DE ESPÉCIES DE eucalyptus E Corymbia POR MEIO DE BROTAÇÕES EPICÓRMICAS

L eia- s e:

In vitro ESTABLISHMENT OF Eucalyptus AND Corymbia SPECIES FROM EPICORMIC SHOOTS

ESTABELECIMENTO in vitro DE ESPÉCIES DE Eucalyptus E Corymbia POR MEIO DE BROTAÇÕES EPICÓRMICAS 